\title{
An Approach of Shadow Education in Greece: Sociological Perspectives
}

\author{
Panagiotis Giavrimis \\ University of the Aegean, School of Social Sciences, Mytilene \\ Department of Sociology \\ Theodoros Eleftherakis \\ University of Crete, School of Education, Rethymno \\ Department of Preschool Education \\ Gerasimos Koustourakis \\ University of Patras, School of Humanities and Social Sciences \\ Department of Educational Sciences and Early Childhood Education
}

Received 27 September 2018 - Revised 30 November 2018 • Accepted 11 December 2018

\section{Abstract}

\begin{abstract}
The purpose of this research was to investigate the phenomenon of shadow education in Greece during the second decade of the $21^{\text {st }}$ century, focusing on the differences between formal and shadow education, the characteristics (of shadow education) and the reasons of its existence. The results showed that the liberalization of education during the recent decades was accurately implemented in the institution of shadow education. Knowledge is becoming a commercialized product and the choice for private education is made through private-financial criteria. Restrictive and maladaptive educational policies and decisions about the educational needs of Greek students exacerbate the purposes of shadow education development.
\end{abstract}

Keywords: Greece, shadow education, tutoring, private lessons, students, graduates.

\section{Introduction}

The institution of shadow education is mentioned as such in Western Europe, Southeast Asia and Africa, as Buxiban in Taiwan, as Hagwon in Korean, as Juku in Japanese, as Crammers in Britain, as Preuniversitario in Spanish, as Tutorials in India, as Dersane in Turkey, etc. (de Castro \& de Guzman, 2014; Kennedy, 2007). In countries like Japan, Cambodia, Malaysia, Taiwan, Korea, India, this institution has been developed so much that it has been thought to be another business sector (Aslam \& Atherton, 2012; Baker et al., 2001; Kenayathulla, 2013; Song, Park \& Sang, 2013; Zhan et al., 2013). Indeed, after the disappearance of the Second World societies, that is the fall of former Communist regimes in Eastern Europe (Giddens, 2006), shadow education was expanded in these countries as a way of rapid adaptation to new socio-economic changes, because it was difficult for the public school system to incorporate these changes directly

(C) Authors. Terms and conditions of Creative Commons Attribution 4.0 International (CC BY 4.0) apply. Correspondence: Panagiotis Giavrimis, Assistant Professor, Department of Sociology, University of the Aegean, Postal address: Pamfilis 17, 81100 Mytilene, GREECE. E-mail: giavrimis@soc.aegean.gr. 
(Silova, 2010). Shadow education is associated with the general privatization of education and the introduction of principles and rules of neoliberal market to learning.

The privatization of education is associated with neoliberalism, and especially with the "small state-free market" approach of the 1980s (Ball \& Youdell, 2007: 13). This juncture between public and private sector emerges from the new dimensions of the interrelationship between neoliberal policy and state-economy and the commercialization of goods (Getimis \& Kafkalas, 2003), while social relations and human values are alienated and identified with exchange value (Narosky, 2007: 103-104). The privatization of education affects the operation of public education, and its organization, its curricula, student assessment, teacher training and salaries, and students' and their parents' perception of schools and teachers (Ball \& Youdell, 2007: 16). Within this context, the signification or meaning that individuals give to their needs, and mostly for more or different education, regulates their behavior and forms the conditions of growth of the private education in a neoliberal environment with many technological characteristics. Individuals in the competitive and individual-based social and educational post-modern environment regard shadow education in Greece as an inevitable factor that will enable them to cope with the inconsistencies of public education system and derive the benefit from their increased institutionalized cultural capital (Bourdieu, 1997) in the case that they would succeed to the higher education entrance exams (Kassotakis \& Verdis, 2013; Kelpanidis \& Polimili, 2012; Papamathaiou, 2014; Sianou-Kyrgiou, 2006, 2008).

\section{Shadow education in Greece}

Shadow education school, as an institution in Greece, was established in the beginning of the 2oth century, through the applicable educational policies as a compelling social reality, which can take the form of legal non-formal education, or illegal-undeclared "private" (personalized) education (Dimou, 1999). Although, shadow education is not a mandatory "social institution", it is "widely recognized" as a necessary social activity. The development and the function intensity of shadow education (if we think that this begins in elementary school and is maximized in high school) emerges as an objectified social reality formed in Greece and makes this institution an inevitable success factor in educational system. According to Tsaousis, along with the national education system, a system of educational services has been developed ${ }^{1}$, which is divided in two sections: the first one was informally incorporated in public education, while the other seeks a position in the national education system (Nova-Kaltsouni, 2010: 149-150). In Greece, shadow education has basically two forms: (a) the legal non-formal education accommodated in specific building facilities with registered staff and function license granted by the Ministry of Education, which has the name "frontistiria" (shadow education schools), and (b) the illegal form of undeclared work in private courses, known as "idiaitera mathimata" (private lessons, tutoring), which is not accommodated in specific place but it often occurs at student's residence. The second form belongs to undeclared work, and is often held (without the permission of Greek educational legislation) by several teachers, who permanently work at public schools. In recent years, with the proliferation of the internet, many forms of online real time or asynchronous shadow education have been expanded.

It was found that the more advanced the school level, the more students attend private education. In Primary School, children attend courses in order to learn foreign languages, since it is the only reliable way to obtain certification qualifications. In Junior High School, students, apart from foreign languages, receive extracurricular support for prestigious subjects of the curriculum such as Language, Mathematics, and Physics. The same happens in the first grade of Senior High school, while during the attendance to the $2^{\text {nd }}$ and $3^{\text {rd }}$ grade of Senior High school students attend shadow education or private lessons only for "interesting subjects", subjects which are needed for students' entry to higher education (Vlachos, 2008: 156-158). A survey made by Kassotakis and 
Photiadou (1996, op. cit., in Kassotakis \& Verdis, 2013: 99) in students of the third grade of Senior High School showed that $75.3 \%$ attended courses at shadow education schools (frontistiria) and $36.5 \%$ were being tutored (privately). In a survey (2000) in about 3,500 first-year university Greek students, it was noted that over $80 \%$ of these students had attended shadow education schools for their entry to higher education, 50\% had attended private lessons, while one student out of three had paid for both forms of shadow education (Psacharopoulos \& Papakonstantinou, 2005).

In a survey conducted by Kelpanidis and Polymili (2012) in 596 students in the third grade of Senior High school in urban and suburban areas in Thessaloniki, researchers found that: (a) students of this grade were spending 11-20 hours at shadow education schools or private lessons; (b) 93.2\% were attending shadow education; (c) 48.8\% were paying 300-400 $€$ a month for these lessons; (d) 20.7\% were paying more than $400 €$; and (e) the rationale behind choosing one or both kinds of the shadow education was that students (and their parents) desired to be better trained and prepared for the exams, to have a better control of their progress and to be taught more effectively than they were in the public school.

In a survey of Metron Analysis ${ }^{2}$ in 2007, it was found that: (a) two thirds of the parents viewed negatively the educational system; (b) after finishing the first grade of high school, $76 \%$ of students were attending classes in context of shadow education; and (c) more than $90 \%$ of parents believed that shadow education helps students achieve their aims (OEFE3, 2007). According to a survey carried out from 2009 to 2013 by Palmos Analysis ${ }^{4}$ in 534 parents of high school graduates it was also found that: (a) the lack of extracurricular support to students of High School is associated with economic distress (47\%). 91\% of families with incomes between 1,500 and 2,000€ provide to their children additional extracurricular help. For families with income over 2,00o $€$, the percentage rises to $94 \%$, while for families with an income of $500 €$, the percentage reaches $65 \%$ of families; (b) one to three students who have extracurricular support in high school does not take part in national exams, though they are coming from low income groups; and (c) the failure rate for students with extracurricular support is 12\%, while for students without high school extracurricular support is tripled (35\%) (Papamathaiou, 2014). In a study from the University of Macedonia (2012) on shadow education in Prefecture of Attica, it was shown that: (a) the initial selection criteria for shadow education are the quality of staff, students' performance and achievements (45\%), and finally, the cost (37\%); and (b) parents prefer shadow education schools than private lessons because of their lower cost, their better organization and students' needs.

The sociological research, investigating the phenomenon of shadow education schools in Greece, has concluded that not only methods, programs and examinations but also language teaching and pedagogy has contributed to the exacerbation of this phenomenon (Kassotakis \& Verdis, 2013). Private education was spread to such an extent from the beginning of its existence, despite the fact that it appeared in the 19th century, although the reasons of its existence were not the same as today.

In Greek literature, the Greek government's current educational policy on teachers' employment, the restrictive policy of the Greek Government on students' accessibility in higher education and the importance of obtaining a degree and professional success are presented as causes of the phenomenon of shadow education school (Sianou-Kyrgiou, 2008). Indeed, the prestige, income growth and the specialization of individuals in the labor market intensified this phenomenon of admission to higher education and hence the development of shadow education (Kontogianopoulou-Polydorides, 1997: 31-33). Furthermore, the excessive growth of public sector over the past decades, the high absorption of higher education graduates in various forms (permanent position, permanent or part-time employment contract etc.) and the objectification of recruitment criteria consolidated the importance of "collecting" qualifications for social mobility and success in life. Vlachos (2008) notes that the traditional evaluation of the student in Greece and the connection with the qualifications that are necessary for the transition to higher education, the decreasing disbursement on education, the discontinuities of curricula between 
grades, the tight timetable and the absence of time in order to meet the school work requirements, the mass of textbooks, the lack of infrastructure and, finally, the weaknesses of teachers' retraining are the factors which are contributing to the spread of shadow education.

In the present article, we are presenting part of the outcomes from a wider research study that explores the influence of the shadow education on Greek educational system and its impact on learning and the transformation of public education in consumer product. The purpose of this research was to investigate the phenomenon of shadow education school in Greece, focusing on the differences between this and formal education system, its characteristics and its causes.

\section{Method}

This study, which is part of a wider research, was carried out during the academic years 2015-2016 and 2016-2017 and lasted from September 2015 till May 2017 with the participation of individuals (Universities' students and secondary education graduates) who lived in the Prefectures of North Aegean islands. The triangulation was chosen in the research since were used in a supplementary way the tools of questionnaire and structured interview (Cohen, Manion \& Morrison, 2008; Creswell 2011).

\subsection{Participants}

The sample of our quantitative research consists of 418 respondents, of which 148 (35.4\%) are male and 270 (64.6\%) are female. Regarding to their fathers' level of education (from primary to higher education), it was shown that 76 fathers (18.2\%) have completed primary school, 54 (12.9\%) have graduated from junior high school, 134 (32.1\%) have completed senior high school and $154(36.8 \%)$ are university graduates. Regarding to their mothers' educational level, primary school is completed by 66 (15.8\%) mothers, junior high school is completed by 61 (14.6\%), senior high school is completed by 169 (40.4\%) and 122 have graduated from university or technological educational institutes (29.2\%). At the same time, 44 structured interviews were received from 11 men and 33 women, whose ages ranged from 24-35 years, and they were all graduates from university or technological educational institutes.

\subsection{Research instruments}

A questionnaire and the structured interview were chosen for the data collection about shadow education. The structure of questionnaire was based on: (1) respective research studies and findings from international bibliography; (2) the School Curriculum for the subjects (YPEPTH, 2002, 2003); and (3) YPEPTH's guidelines on the particular course. The questionnaire included questions related to the structure and function of public education, the comparison with private education, the usefulness and importance of shadow education, its extent, and cost.

The structured interview was necessary for the researchers in order to interpret what people think about the characteristics and development of shadow education in Greece. In essence, there were used predefined questions that have specific order in the interview process with the interviewee (Robson, 2007). The structured interview consisted mainly of questions in order to clarify the reasons and causes of shadow education and its differentiations from formal education. 


\section{Results}

Throughout the description of the findings, there were used quantitative descriptive methods, which were combined with reports of qualitative research, in order to be better analyzed.

In question about comparing public and private education and if the first one is worse than the second in terms of quality, 34 (8.1\%) respondents answered that public schools do not fall short of private ones at all, 30 (7.2\%) respondents answered that public schools do not keep up private education, 100 (23.9\%) individuals answered that public schools are below average in relation to the quality of education they provide, 165 (39.5\%) individuals said that public education is enough below average, $86(20.6 \%)$ respondents said that public schools fall far short in relation to private ones, while 3 (0.7\%) people answered that they do not know. As stated above, the majority of people believe that public schools are little below average from private ones. The interviewees said characteristically that:

"The education system is not working properly due to many endogenous and exogenous factors ... Firstly, I think ... there are not given enough funding to education from state, compared with European standards ... because in Greece, it is given in education approximately 2.4\% of GDP, while in Sweden, it is given about $10 \%$ of GDP ... in addition I believe ... in public schools, the majority of teachers do not work properly" (Interview 12 - I.12).

"Teachers are not mindful of their job ... In addition, if students were interested of school work ... they would get the knowledge they need from public school and they would not be resorted to private schools and shadow education schools"(I.41).

When the research subjects were asked if during their student life they attended some kind of shadow education, 278 (38\%) respondents from all 720 stated that they attended shadow education. From them, 211 (29\%) referred to a specific course, 128 (17.8\%) additional teaching support, 78 (10.8\%) said that they attended not only shadow education but also private lessons and $25(3.5 \%)$ said that they did not attend anything. The most of the interviewees (37 individuals, 84.1\%) argued that this is "a phenomenon that you cannot escape from". Additionally, few individuals (2 persons, $4.5 \%$ ) said that they did not attend any lesson because their parents "did not have any money to spend" and some interviewees (5 persons, 11.4\%) said that they had attended only the extracurricular additional instructional support offered by the public senior high schools:

"The public additional support .... those extra hours. I went for two weeks in math

... I think the two weeks were enough"(I.24).

As to whether the individuals of the sample consider shadow education unnecessary cost without return, 197 (47.1\%) respondents answered negatively, 96 (23\%) answered 'a little bit", 72 (17.2) answered moderately, 37 (8.9\%) reported that it is enough unnecessary and 12 (2.9\%) answered that they consider it unnecessary. For the $70.8 \%$ of people, it is little unnecessary or necessary, while $\mathbf{1 1 . 8 \%}$ of them say that it is quite or much unnecessary for them. The interviewees pointed out that there was a kind of exploitation. The following comments are characteristic:

"Yes, there was a kind of financial exploitation, due to the increase of tuition fees using as a pretext the lesson repetitions and the larger classes"(I.31).

"Eh ... basically, these schools are involved with commerce that definitely makes for competition between them" (I.8).

training:

The interviewees also noted that there was an increased cost of the weekly or private 
P. Giavrimis, Th. Eleftherakis \& G. Koustourakis - An Approach of Shadow Education in Greece: ...

"In general you could say that the extra-curricular support costs from 70 to 150 euro per week. The amount was ranged in different levels depending on the number of courses" (I.15)

"Specifically, the third grade of high school with a full package of course costs around 110 euro a week" (I.7)

"The weekly cost of a family especially for shadow education schools was about 250 euro"(I.36).

To the question whether they consider this training important for the entrance in Universities or Technological Educational Institutes, 162 respondents (38.8\%) answered that it is very important, 185 (44.3\%) said enough, 45 (10.8\%) answered moderately yes, 13 (3.1\%) said a little bit and 8 respondents (1.9\%) that it is not at all. Therefore, $83.1 \%$, of them think that additional educational support is quite or very important for the university entrance, while a small percentage of $5 \%$ opposes this view. Similar results are noticed in the question: "If there was lack of shadow education in the current educational system, do you think that there would be more barriers in university entrance?" 22 respondents (5.3\%) disagree with this view, 36 (8.7\%) slightly agree, 66 (16\%) agree moderately, 166 agree (40.3\%) and 122 respondents think that this is true (29.6\%). Interviewees answered to the specific questions as follows:

"I attended shadow education for the simple reason of success in higher education" (I.31).

"A child ......... attends shadow education schools because he does not care to entry higher education" (I.44).

"It is generally thought that if you do not attend this kind of lessons, you have no chance to entry in higher education and this mainly comes from the fact that most schools have serious shortages" (I.25).

"It is widely known that most shadow education schools have well prepared students for the exams. So, every family prefers to give money from their savings for their child's success" (I.19).

In the multiple choice question: "What do you think that contributed in your educational support choice", we received 603 responses. From these, 171 respondents (28.4\%) said that the first reason was the more organized and effective delivery of knowledge than school, 53 (8.8\%) responses focus on the teachers' experience, 118 (19.6\%) responses focus on teachers' interest in students, 140 (23.2\%) said the timely completed curriculum, 49 (8.1\%) mentioned the good ratio of learning benefit-cost, and 72 (11.9\%) focus on the information about the possible choices of schools. Some interviewees stated answering to the specific question:

"I believe that it is more the insecurity that parents feel about the ability of public school to help their children get adequate knowledge" (I.4).

"Many teaching hours are lost, teachers do not have time to complete timely the curriculum, the majority of students make trouble and all these have as a result the interruption of the lesson and the retardation of the education process"(I.13).

"Shadow education school has specific curriculum, specific days and hours where the courses are conducted and the child has not the ability to change it" (I.3).

"In private lessons, the student can make a choice of his teacher" (I.21).

From the above extracts arises that it is important for every student to have a teacher next to him, who can make him learn and understand easier.

The choice of a specific shadow education school is done for the following reasons: The most important factor is the quality of the provided educational services [203 replies in total 883 responses (23\%)]. The second reason is the smaller student groups [151 responses (17.1\%)]. The 
third reason is the reliability of the specific shadow education school [149 responses (16.9\%)]. The fourth reason is its reputation [115 responses (13\%)]. Other reasons are friends' and relatives' opinions [75 responses (8.5\%)], the "distance from home" and "what others suggest" [65 responses $(7.4 \%)$ ] and, finally, financial reasons [6o responses (6.8\%)]. Another remarkable thing is the fact that $23 \%$ of the respondents stated that the quality of education is the prime factor in selecting a particular shadow education school in contrast to financial reasons, which possess the last position in this list (6.8\%). The argumentation of the universities graduates of the sample on the reasons that they had chosen to attend in shadow education is characteristic:

"A shadow education school, that has a good reputation and good teachers. Secondly, I would like it to be relatively close to my home, so I can have easy accessibility in case of adverse weather conditions and not to lose a lot of time from my schoolwork. Thirdly, I would try to find out a cheaper one (if this is possible) in order to pay the fees from my paycheck" (I.40).

"The criterion of my choice was the fame and success of the shadow education school" (I.19).

"The main criterion for me has always been the teachers' experience and communicability"(I.26).

"Worthwhile, the teachers were very good. They did their job properly. That's why they were paid for! They made me understand new knowledge and be interested in all courses. This was important for me in order to overcome several difficulties" (I.30).

\section{Discussion and conclusions}

Shadow education is not a phenomenon that emerged neither at recent decades nor during this century, but has made his appearance long ago. However, the current form and the excessive growth cause several questions about the role of public educational system, and the involvement of private sector. The public sector has reduced its participation in providing education to the citizens. As a result, education in most economic developed industrial countries has been commercialized and the education content and outcomes acquired exchange value (Abrams, 2016; Apple, 2000, 2006; Simons, Lundahl \& Serpieri, 2013).

In our study, the majority of people view public education negatively, associating their opinion with the function and structure of the education system, its funding and the quality of teachers' work. These findings are consistent with other relevant research studies in Greece, which have been reported before, and confirm the weakening of the welfare state, which is affected by the major changes imposed from liberalized society (Grolios \& Kaskari, 2005; Sianou-Kyrgiou, 2008). Thus, the state in order to be able to cope with the challenges and be part of the economic and competitive market is making its services tradable commodity (Ekonomou, 2004). All these are validated by the finding that only a small percentage of people (ranging below 5\%) was not included in shadow education. The historicity of the institution of shadow education schools which was not addressed in an appropriate manner by the respective education policy, and the prestige which was attributed by Greek society to every university graduate, were the reasons for the prevalence of the institution and high expenditure by Greek households for their children's education (something that was recorded by official state entities). The weekly cost for shadow education can reach up to 250 euro. The need for monitoring this institution for students' success in school and in admission to higher education is reflected both in the words of the interviewees and the quantitative findings of our research study, and in other studies conducted in Greece (Kelpanidis \& Polimili, 2012; Macedonia University, 2012; Papamathaiou, 2014). This was helped by the insistence of Greek government for a limited number of students admitted in universities, something that was remained in effect for many years but has been partially lifted in our days. The 
occasional educational policies, which were strengthened by the restriction in students' grades or the number of students' admitted to universities, have intensified the problem of competition and educational inequalities and made shadow education a parallel road to formal education for students' success, i.e., university entrance (Kyridis, 2003; Psacharopoulos \& Tassoulas, 2004; Sianou-Kyrgiou, 2006, 2008, 2010). The endorsement of degrees is evident in every feature of educational system. Educational policy opposes its contradictory symbols. On one hand, it upholds the equal opportunities and its democratic character and, on the other hand, the pupils and their families are becoming "customers" of the commercialized private education. The ideological progressiveness of education does not conform to the widening of social inequalities, the non-recognition of the diversity of the student population and the prevalence of economically privileged "clients".

On one hand, the Greek unions of shadow education schools, through their own research studies, advertise and emphasize the importance of their existence for the students' success, and, on the other hand, the state education policy cannot cope with the increased needs of students (OEFE, 2007; Papamathaiou, 2014). In this context, the liberalization of education affects the way of funding, service provision and also, parameters such as supply and demand for services, availability, quality, and access to them (Apple, 2000, 2006; Robertson, 2010; Robertson, Bonal \& Dale, 2002; Simons et al., 2013). Simultaneously, it redefines the role of the state in the formation of educational policy and its practice. The choice of shadow education schools is made with market practice conditions, supply and demand, as a product that is advertised through its results, the quality of service, the reliability and satisfaction of the "client" (locality, economic criteria). The competition is not only between the public and private sectors, but also between business interests on the market of shadow education. The speculation against public sector, which is unable to respond because of its unilateralism and inelasticity, can lead to a dualism of educational services by restricting the access to qualitative education of poor social layers, which will have as a result the increasing of social inequalities, more commercialization of education and the reproduction of social hierarchy.

In conclusion, liberalization of education during last decades has been the institution of shadow education in Greece very well. Knowledge is becoming a marketable product and the preference for private education services from the public is made through private and economic criteria (Abrams, 2016; Apple, 2006; Robertson et al., 2002). Restrictive and maladjusted educational policies in Greece and decisions relating to individuals' needs support the development of this institution, highlight the exchange value of objectified cultural capital of the individual and exacerbate social inequalities. The paradox is that the Greek educational system (which is thought to be democratic) and the "equality of opportunities" are invalidated in daily practice in favor of the privileged individuals, who have the ability to pay for educational services. The declining state investment in Greek education creates individuals educational and socially disqualified, who do not have equal access to learning and knowledge resources. The elimination or even restriction of the institution of shadow education is a complex issue, which must rely on changing the education culture, on the reform of function and structure of education and the orientation change of the educational system (which is based only on the examinations).

Notes:

1. It should be noted that shadow education is called "parapaideia" in Greek. On the one hand, the prefix, "para-" carries two connotations: (1) along/in parallel with something; and/or (2) against something; on the other hand, the main word "paideia" means education in the wider and narrower sense. Thus, the signification of "parapaideia" meets the reality of education in Greek: "parapaideia" is an education that runs (1) along/in parallel with and/or (2) against the mainstream education.

2. Metron Analysis is a Greek company of social, political and market research. 
3. The abbreviation OEFE means Greek Confederation of Educational Institutes of School Support and Evening Schools.

4. Palmos Analysis is a Greek company of market research.

\section{Acknowledgements}

This research did not receive any specific grant from funding agencies in the public commercial, or not-for-profit sectors.

The authors declare no competing interests.

\section{References}

Abrams, S. E. (2016). Education and the commercial mindset. Cambridge, Massachussets, and London: Harvard University Press.

Apple, M. (2006). Educating the 'Right' Way: Markets, standards, God, and inequality. New York: Routledge.

Apple, M.W. (2000). Official knowledge. Democratic education in a conservative age. New York: Routledge.

Aslam, M., \& Atherton, P. (2012): The 'shadow' education sector in India and Pakistan: The determinants, benefits and equity effects of private tutoring. ESP Working Paper 38, Budapest: Education Support Programme, Open Society Foundations.

Baker, D. P., Akiba, M., LeTendre, G. K., \& Wiseman, A. W. (2001). Worldwide shadow education: Outsideschool learning, institutional quality of schooling, and cross-national mathematics achievement. Educational Evaluation and Policy Analysis, 23(1), 1-17.

Ball, S., \& Youdell, D. (2007). Hidden privatisation in public education. Preliminary report. Education International $5^{\text {th }}$ World Congress. July 2007. London: Institute of Education, University of London. Retrieved 25 August 2018, from https://pages.ei-

ie.org/quadrennialreport/2007/upload/content trsl images/630/Hidden privatisationEN.pdf.

Bourdieu, P. (1997). The forms of capital. In: A. H. Halsey, H. Lauder, P. Brown, \& A. S. Wells (Eds.), Education: Culture, economy, and society (pp. 46-58). Oxford: Oxford University Press.

Cohen, L., Manion, L., \& Morrison, K. (2008). Research methods in education. Athens: Metaixmio.

Creswell, J.W. (2011). Educational research. Planning, conducting, and evaluating quantitative and qualitative research. Athens: Hellin Editions.

de Castro, B. V., \& de Guzman, A. B. (2014). From scratch to notch understanding private tutoring metamorphosis in the Philippines from the perspectives of cram school and formal school administrators. Education and Urban Society, 46(3), 287-311.

Dimou, G. (1999). Tutorial activity in Greece. Empirical investigation of the phenomenon. Athens: Gutenberg (in Greek).

Ekonomou, Ch., (2004). National health policies in Greece and in European societies. Athens: Dionikos (in Greek). 
P. Giavrimis, Th. Eleftherakis \& G. Koustourakis - An Approach of Shadow Education in Greece: ...

Getimis, P., \& Kafkalas, G. (Eds.). (2003). Metropolitan governance: International experience and Greek reality. Thessaloniki: Ziti (in Greek).

Giddens, A. (2006). Sociology (5th ed). Cambridge: Polity Press.

Grolios, G., \& Kaskari, G. (2005). The contribution of PASOK in the promotion and implementation of neoconservative neoliberal restructuring in education. Antitetradia tis ekpaidefsis, 73-74.

Kassotakis, M., \& Verdis, A. (2013). Shadow education in Greece: Characteristics, consequences and eradication efforts. In: M. Bray, A. H. Mazawi \& R. G. Sullana (Eds.), Private tutoring across the Mediterranean: Power dynamics and implications for learning and equity (pp. 93-113). Rotterdam: Sense Publishers.

Kelpanidis, M., \& Polimili, K. (2012). The prevalence of tutoring and the devaluation of the Greek school education. Nea Paideia, 143, 1-24 (in Greek).

Kenayathulla, H. B. (2013). Household expenditures on private tutoring: Emerging evidence from Malaysia. Asia Pacific Education Review, 14(4), 629-644.

Kennedy, K. J. (2007). Barriers to innovative school practice: A socio-cultural framework for understanding assessment practices in Asia. Paper presented at the Redesigning Pedagogy: Culture, Knowledge \& Understanding Conference, Singapore, 28-30 May 2007. Retrieved 18 August 2018, from http://neqmap.unescobkk.org/wp-content/uploads/2015/o9/Barriers-toInnovative-School-Practice-a-socio-cultural-framework-for-understanding-assessmentpractices-in-asia.pdf.

Kontogianopoulou - Polydorides, G. (1997). Sociological analysis of the Greek education. Athens: Gutenberg (in Greek).

Kyridis, A. (2003). Inequality in Greek education and access to university (1955-1985). Athens: Gutenberg (in Greek).

Narosky, S. (2007). Economic anthropology: New directions. Athens: Savvalas.

Nova-Kaltsouni, Ch. (2010). Sociology of education. Athens: Gutenberg (in Greek).

OEFE (2007). Attitudes and habits of parents with children at secondary school students across schools and remedial teaching. Retrieved 5 May 2014, from www.oefe.gr/Portals/o/presskit/ereunes oefe/EREYNA METRON_GIA SFBEparents.pdf (in Greek).

Papamathaiou, M. (2014). Four in five students make tutorial. Vima (27/01/2014). Retrieved 5 May 2014, from http://www.tovima.gr/society/article/?aid=561270 (in Greek).

Psacharopoulos, G., \& Papakonstantinou, G., (2005). The real university costs in a "free" higher education country. Economics of Education Review, 24(1), 103-108.

Psacharopoulos, G., \& Tassoulas, S. (2004). Achievement at the higher education entry examinations in Greece: A Procrustean approach. Higher education, 47(2), 241-252.

Robertson, S. (2010). Corporatisation, Competitiveness, Commercialisation: new logics in the globalising of UK higher education. Globalisation, Societies and Education, 8(2), 191-203.

Robertson, S., Bonal, X., \& Dale, R. (2002). GATS and the education services industry: The politics of scale and global reterritorialization. Comparative Education Review, 46(4), 472-496.

Robson, C. (2007). Real world research. Athens: Gutenberg.

Sianou-Kyrgiou, E. (2006). Education and social inequalities: The transition from secondary to higher education (1997-2004). Athens: Metaixmio.

Sianou-Kyrgiou, E. (2008). Social class and access to higher education in Greece: Supportive preparation lessons and success in national exams. International Studies in Sociology of Education, 18(34), 173-183. 
Sianou-Kyrgiou, E. (2010). Stratification in higher education, choice and social inequalities in Greece. Higher Education Quarterly, 64(1), 22-40.

Silova, I. (2010). Private tutoring in Eastern Europe and Central Asia: Policy choices and implications. Compare: A Journal of Comparative and International Education, 4O(3), 327-344.

Simons, M., Lundahl, L., \& Serpieri, R. (2013). The governing of education in Europe: Commercial actors, partnerships and strategies. European Educational Research Journal, 12(4), 416-424.

Song, K. O., Park. H. J., \& Sang, K. A. (2013). A cross-national analysis of the student- and school-level factors affecting the demand for private tutoring. Asia Pacific Education Review. https://doi.org/10.1007/s12564-012-9236-7

University of Macedonia (2012). Measuring users attitudes towards tutorial education in Attica. Research Unit for Public Opinion and Market, University of Macedonia. Retrieved 5 May 2014, from www.real.gr/Files/Articles/Document/182104.pdf (in Greek).

Vlachos, D. (2008). Quality in education. Research to evaluate quality attributes of the system of primary and secondary education. Athens: Ministry of Education and Religious Affairs, Pedagogical Institute (in Greek).

YPEPTH (2003). IIFSPSPs (Intra-thematic Integrated Framework of Studies Programmes; DEPPS in Greek). Athens: Pedagogical Institute (in Greek).

YPEPTH [Ministry of Education and Religious Affairs] (2002). ASPs. (Curriculums; APs in Greek) of Compulsory Education. Vols. A and B. Athens: Pedagogical Institute (in Greek).

Zhan, S., Bray, M., Wang, D., Lykins, C., \& Kwo, O. (2013). The effectiveness of private tutoring: Students' perceptions in comparison with mainstream schooling in Hong Kong. Asia Pacific Education Review, 14(4), 495-509. 
P. Giavrimis, Th. Eleftherakis \& G. Koustourakis - An Approach of Shadow Education in Greece: ...

C O A S 